Jelena Šesnić

Faculty of Humanities and Social Sciences

University of Zagreb

\title{
Bogdan Raditsa, the 1970s, and the Question of Croatian Emigration
}

The article contends against a fallacious assumption that Croatian political emigration in the second half of the twentieth century formed a homogeneous and monolithic whole, while it is rather the case that it was fissured and destabilized by each successive wave of emigrants. This differentiation is here presented in a number of contributions by Bogdan Raditsa, written in the 1970s and published in Hrvatska revija predominantly and occasionally in other emigration journals as well. Raditsa, as one of the nestors of the "new emigration" occurring after World War Two, notes a trend of increasing radicalization of the emigrants entering political arena as a result of reprisals following the suppression of the Croatian Spring in 1971. The 1970s are thus seen as a pivotal decade in which generational distinctions within Croatian emigration were manifested in a number of high-profile radical and terrorist acts committed by the latest wave of emigrants. Raditsa's position indicates his adherence to democracy and liberalism on the model of the United States, while he subjects different models of political activism in emigration to reasoned scrutiny. His political analysis is not only a record of a diasporic intellectual disposition but also an incisive comment on the vicissitudes of Croatian politics in the stifling embrace of the Cold War. Consequently, an argument is forwarded that calls for a definitive inclusion of political diaspora into Croatian Cold-War history, while suggesting that such a goal might be achieved among other things by a sustained reception of Raditsa's formidable oeuvre.

Key words: Bogdan Raditsa, Croatian emigration, the Croatian Spring, the 1970s, terrorism

This short essay-more than appropriately designated as a "working paper"-comes from a larger project that proposes to trace a, tentatively titled, 
transnational poetics of Croatian American diasporic writing in the twentieth century. As a project pursuing Croatian American topics, it thus reflects the most recent calls for transnational American Studies, even if its precise methods and scope have yet to be declared. ${ }^{1}$ Finally, as a fragment of yet another larger undertaking, a still unrealized but sorely needed cultural history of Croatia in the Cold War, it is a historical investigation plain and simple, a work based on primary historical sources scattered among numerous Croatian and U.S. archives, awaiting future researchers.

At the outset, it is worth highlighting at least two principal goals that this essay, as a part of a more ambitious effort, aims at fulfilling. The first is to propose that diasporic intellectuals in the vein of Bogdan Raditsa (alternatively, Radica), and the work they carried out while in political exile, form a key, if missing, part of Croatia's cultural history in the twentieth century, especially during the period of the Cold War when they were pointedly excluded from participating in the public life of socialist Yugoslavia. The second goal is to point out what is one of the most charged periods of post-WW II Croatian emigration to the West, the turbulent 1970s. The validity of this latter assertion will be tested in the remainder of the essay. ${ }^{2}$

Boris Maruna, both a poet and long-term emigrant himself, reminisces in the afterword to Vječni Split about Bogdan Raditsa and his staunch liberal orientation, placing him within the American political mainstream (188; similar observations are proffered by Ivo Banac in the preface to the same edi-

1

For more on this recent disciplinary orientation and a tentative articulation of its scope, goals, and methodology, cf. Fluck and Pease; Journal of Transnational American Studies (an e-journal hosted by the University of California).

2 When I say "missing," I have in mind the almost non-existent reception in Croatia of Raditsa's truly formidable, quantitatively speaking, oeuvre. It is deplorable that such an output - truly transnational in terms of its themes, as well as in terms of the author's frequent changes of residence, broad cultural and linguistic literacy, and political acumenis still largely unrecorded in the Croatian public sphere and its intellectual hubs. One may hope that better times are in the offing since the announcement of the founding of the Raditsa research center in Split, his hometown. For an elaboration of this argument, cf. Đurešković. 
tion: cf. 8). Maruna observes Raditsa's added qualities which turn him into one of the invaluable personages amongst the Croatian intellectuals scattered worldwide: "For Bogdan Raditsa has always been willing to talk, dispense advice, discuss things, which leads me to conclude that he is preeminently the man of the agora, the piazza, immersed in the Split mores" (188; if not indicated otherwise, all translations are by the author). Moreover, it is Maruna's belief that Raditsa was one of the "truest men of the Mediterranean in Croatian political emigration. This mostly means that he has carried within himself all the virtues and vices not only of his native Split but of the entire Mediterranean area, as well, which, as a historian, he intimately knew and, as its true son, loved above all" (189).

Bogdan Raditsa (1904-1993), therefore, cuts a formidable presence in the political life of Croatian emigration in the second half of the twentieth century from whatever angle we look at it. Judging by his biography ever since he made it into top journalistic circles and subsequently into the diplomatic service of the Kingdom of Yugoslavia in the 1930s and 1940s, his versatile career was increasingly marked by an unmistakable and genuine political nerve. Initially, though, as a journalist and a foreign correspondent in a number of leading Yugoslav newspapers and journals, he was more interested in all manner of cultural matters, ranging from literature to history to philosophy. From the beginnings of his public engagement, Raditsa found himself in a unique position to experience firsthand the rising and conflicting political ideologies engulfing Europe in the run-up to the Second World War. His pre-war activities already carry unmistakable traces of his later liberal and democratic commitments, while his acquaintance with different forms and features of the rising fascism and ideologies on the left made him sensitive to their lures and misleading arguments.

The next turning point for Raditsa came in the immediate wake of World War Two, when he found himself back in Croatia and Yugoslavia just as the new regime was taking hold. The scenes later described in his memoires Hrvatska 1945 (Croatia 1945) bear forceful testimony of the initial, quite bloody and violent phase of consolidation of the new order. After witnessing 
the ordeal of the new society for a short while, Raditsa left the country in late 1945 and would not return, it turned out, for the next forty-five years. After that he only visited Croatia in the early 1990s, shortly before his death in 1993. During that time he lived in the USA, spent his summers in Italy (his wife, Nina Ferrero, was Italian), made his home a hub for Croatian émigrés and other anti-communist and anti-totalitarian opposition, while his public efforts as a professor of political science and history, commentator, lecturer, and journalist resonated in both Croatian- and English-speaking communities. Grateful to America for his and his family's freedom, safety, and opportunities, Raditsa implicitly spells out the role of the post-war "DP [Displaced Persons] intelligentsia," harbored by America, "doomed to death" in their home countries, to which he himself belonged: “... the new immigrant intelligentsia must first mold itself to the American pattern and try to establish itself in the growing American intellectual tradition" ("Some Displaced").

For the purposes of this format, I will not so much try to rehabilitate Raditsa, since neither he nor his works need that kind of attention, but will use his high stature and his reputation as one of the leading Croatian political émigrés to highlight a series of ruptures and discontinuities observable in the otherwise flatly designated phenomenon, oftentimes still used in a derogatory sense, of Croatian political emigration. Let me take a step back here in order to remind the reader that this ambivalent term was in fact coined by the Yugoslav socialist regime, especially its arm that was authorized to deal with the considerable segment of its citizens that was leaving the country for one reason or another. In order to ideologically differentiate among these, the category of "emigration" was prefaced by additional modifiers, such as political, extremist, enemy, or Ustasha, often regardless of the substantive charge behind these categories. ${ }^{3}$ (In case of other antagonistic national or political groups, since the state did not lack enemies, real or invented, other modifiers two high-ranking officers in the YPA (Yugoslav People's Army) which was to be used as "an official textbook ... for the socio-political education of YPA soldiers and seamen" (Domankušić and Levkov n.p.). 
were used, such as "informbiro" or "cominform" for pro-Stalinist and pro-Soviet elements, or "irredentist," which was a code word for Albanian political emigration.) Likewise, appropriate nomenclature was used to designate the apolitical branches of Yugoslav emigrants abroad. If a person happened to land on the list of politically proscribed emigrants, it spelled for him almost by default the loss of all civil rights in Yugoslavia. Such was the case with Raditsa after his sudden defection from the country in 1945.

To go back to the main line of my argument, we need to understand how Raditsa, as a member of the first wave of Croatian political emigration after WW II, considered and assessed the phenomenon of the second wave of Croatian political emigration caused by the crackdown ordered by Tito himself on the reformist forces of the Croatian Spring and happening in the wake of the Spring's violent shutdown in late 1971 and afterwards. The time-frame for my analysis, then, will comprise the ten years stretching from 1970, focusing especially on the ominous 1971, to 1980 and the death of Josip Broz Tito. It is necessary to delimit the scope of our research given Raditsa's prolific production. Beyond these technical observations, another consideration dictates such a focus, which this essay will aim at demonstrating by presenting the main lines of Raditsa's thought as laid out in his contributions to Hrvatska revija from 1970 to $1980 .{ }^{4}$ Writing in early 1970, he calls the crisis permeating Yugoslavia at the dawn of the 1970s "an organic Yugoslav crisis" (1970: 21). He cites other sources contending that the large part of the turbulences occurred due to "deep national conflicts" (ibid.). Even economic questions, pressing as they may have been, stood subservient to the national issue exacerbated due to a deep ideological crisis - the Party and its politics based on Marxism no longer bound the nations in the federation together (1970: 22). Moreover, he considers the national right of self-determination to be one of the major political principles of the twentieth century (ibid.). I have delib- 
erately highlighted this essay as inaugural for the 1970s, since it shows in a nutshell Raditsa's preoccupations for the next ten years and beyond.

In Raditsa's case, in which he was hardly alone, he hailed with enthusiasm the rise of Croatian national awareness that was in evidence at least from 1966 and the fall of Aleksandar Ranković, Tito's right hand and the proverbial almighty chief of the Yugoslav secret police. ${ }^{5}$ When the Spring effectively ended by a military and police crackdown, it signalled for Raditsa a new phase, not only for Croatia, but also for the Croatian diaspora, and, ultimately, for his own political philosophy as he makes clear. This is then why 1971 is so charged a year on many levels. This comes to the fore in the way Raditsa tries to make sense of the violent end of the Croatian Spring, the debacle in Karađorđevo, "the new Croatian catastrophe in Yugoslavia" (Hrvatska 1945, $33,44)$. Up to that point he was still willing to consider the existence of Croatia as a federal unit in the Yugoslav fold. This attitude was in part a reflection of both his idealism and his political realism-his understanding that the West wants Yugoslavia to survive and needs it as an idea.

As we posit 1971 as a turning point, we should first look at the way Raditsa positions himself with regard to the events in Croatia and Yugoslavia before 1971, while considering their imbrications with the Cold-War containment politics of the superpowers. This will show how Raditsa always develops his insights and analyses in the process of triangulating the Croatian strain, its diasporic resonance, and the global Realpolitik to which these two are often subservient. For instance, considering his U.S. public appearances, there are at least two or three major phases to be considered. One is the key propagandist role that, alongside Louis Adamic (alternatively, Adamič), Raditsa played as one of the vocal promoters of Tito and the Partisans' side as principal antifascist factors on the ground in Yugoslavia as they made clear in the critical period of late 1943 and 1944. While initially Tito appreciatliberalisation is argued, among others, by Ante Batović. It is thus probable that a few years later a full-fledged reformist movement might have flourished. Cf. Ponoš 17. 
ed their engagement (to the extent that Raditsa came back to Yugoslavia in 1945), later on he would denounce Raditsa as a "warmonger," when the latter no longer countenanced the situation in Yugoslavia after the war (Hrvatska 1945, 44, 358). In addition, it was almost inevitable that, while at the outset of the Cold War in the 1950s Raditsa's sharply polemical articles critical of the situation in his home country were welcomed by the leading U.S. political and public opinion magazines, this ceased to be the case as the 1960s began. ${ }^{6}$

At that point in time, with Yugoslavia becoming a factor in international relations and a major U.S. ally in the bipolar world, a negative view of Tito and his regime was not endorsed either by the State Department or by the major political journals. So in his late 1970 contribution to Hrvatska revija, he admitted that the official U.S. policy towards Yugoslavia had not wavered during the Cold War, and that it was more than likely that the pro-Titoist direction would remain a mainstay of the State Department's foreign policy (1970: 518, 519). As for his further analyses of U.S. foreign policy in Southeastern Europe, Raditsa on more than one occasion warned against what at times loomed as a possibility in this period: namely, for the Americans to surrender Yugoslavia to the Soviets (1970: 531). Thus it is at that point that Raditsa began to focus his energy more on publishing in a series of Croatian emigrant publications, including Hrvatski glas (Canada), Nova Hrvatska (London, U.K.), the Journal of Croatian Studies (New York City, U.S.A.), Hrvatska revija (Barcelona and München, at the time), and Danica (Chicago, U.S.A.), to mention a few, which spanned the spectrum from left to right. His activities demonstrate a clear diasporic disposition at work, as his texts spread from London to Canada, from the United States to Buenos Aires and, later, to Barcelona and München, to all centers of Croatian emigrant cultural

6 Many of Raditsa's friends recall that he was never one to mince words, as is evident in his 1953 piece on Moscow and Belgrade, in which he unequivocally calls Tito a "dictator" ("Malenkov's"). In a 1951 editorial for The Saturday Evening Post, he took another hard look at the conditions in communist Yugoslavia while trying to make a case against "unconditional aid" "in loans and food supplies" from the West, the United States in particular, to the crisis-ridden Yugoslavia ("Yugoslavia Will Be a New Headache"). 
and political activity.

As it has already been suggested that the global Realpolitik was an axle around which revolved both the status of Yugoslavia and, consequently, the attitude that the politically engaged diaspora took to it, in the remainder of this essay I will first present Raditsa's main international political concerns in this period, 1970-1980, and then embed his view of the Croatian situation in that particular international constellation.

The world at the time was a bipolar world, according to Raditsa, in which Yugoslavia, for better or worse, found itself vacillating between the East and the West (1970: 531). Despite its non-aligned status, or precisely because of it, insofar as that status was a viable political option, the country found itself wooed by the superpowers. This comes to the fore in the 1970s in both a conspicuous and anecdotal manner. Namely, during that decade the country was visited by both the leader of the "free world," i.e., President Nixon, and on few occasions also by Leonid Brezhnev, the General Secretary of the Soviet Politburo. Raditsa invites us to consider the symbolic of the two visitors when he reminds his readers that Nixon also visited Croatia, and Zagreb, during his official visit to Yugoslavia in 1972, unlike Brezhnev, who in 1971 stayed in the ominous (for Croatia) Karađordevo (1974: 3-15; for a description of Brezhnev's visit, cf. Banac). Later on, these two leaders would come to play a prominent role in the process of détente aimed at reducing the tension and geo-political strain resulting from the arms race, when they would sign a bilateral agreement. These developments were assessed at the time by Raditsa in an ambivalent light (1973: 8). During those years he considered international political events within the framework of "a deep moral and political crisis besetting Europe and America" and signaling the decline of the West (1974: 3), which spelled bleak prospects for Croatia.

It is thus inevitable that the coup of 1971 that shook up most Croatian

$7 \quad$ In a related context, that of the assessment of the Croatian Spring forty years later, Rinna Kullaa of Finland considers how the "crisis in Croatia," one of its various names, was narrativized and framed by U.S. intelligence reports, while also placing it tentatively within the context of East-West relations in Europe at the time; cf. Kullaa 93-109. 
institutions, from political to cultural to economic, caused Raditsa to focus on the fate of Croatia and its new wave of emigrants. In accounting for the clash of generations that became observable in the 1970s as scores of new politically hardened candidates flocked to the shores of the old immigration destinations of Croats, such as the United States, it will perhaps be helpful to us to personalize this historical moment by staging it as a dispute between the old and the new guard. The old guard stands represented by staunch political liberals, such as Raditsa, by Croatian antifascist nationalists (the circle around Dr. Krnjević and "his" HSS [Croatian Peasant Party]), or by rightwing nationalists, while the new guard, or the Spring generation as Raditsa dubbed them, was represented by radical lions, many of whom were already politically seasoned by their membership in the League of Communists and now further incensed after they had been turned out in purges, tried and sentenced in staged trials, or simply allowed to leave the country before ending up in prison $(1978: 371 ; 1979: 580)$. Some of these young lions found themselves on the warpath against the regime which only yesterday was extending a promise of a better society and offering a whiff of reformist hope. The new type of Croatian political activist was personified in the figure of the late Bruno Bušić for several reasons, as suggested in the following excerpts:

Bruno Bušić had been a representative of an entirely new Croatian generation ... . He had been brought up in Yugoslavia, where he was publishing even in completely legal newspaper [sic] at the time of the "Croatian Spring," in the early seventies. Of course[,] he already aroused Belgrade's indignation in those days, so that they eventually arrested him. But he was definitely not one who could be politically incriminated with the sins of the past and subsequently discredited in the eyes of the world. (Rullman 16; original in English)

Moreover, "Bušić also shocked many older political emigrants who had left their country because they were fighting Communism. He openly advocated the inclusion of the Croatian Communists in a national united front against the regime in Belgrade" (Rullmann 16). 
How can we account for this shift? A historical sketch might help us here. One of the most publicized events of the Croatian Spring was certainly the strike organized by the University of Zagreb students and led by the student leaders of whom some of the most prominent were Dražen Budiša, Ivan Zvonimir Čičak, Ante Paradžik, and Ivan Dodig. After the students were pressured to end the strike on December 4, 1971, Budiša was reported to have said: "Those who come next will be even more radical than we were" (cf. Jakovina 10), these words ringing as his political testament and sounding all the more ominous in view of the impending trial sentencing the student leaders to multiple years in prison. The subsequent events proved Budiša right, however. The young misfits, now coming mostly from the folds of the Party itself, Tito's prodigal sons, so to speak, began to fill the ranks of the Croatian emigration, bringing with them the ways and means of conducting political combat that the older generation found too radical, violent, and deficient in democracy to help the cause. Already in March 1972, while the backlash against the Spring protagonists was still in force, Raditsa strongly denounced "the rhetoric of so-called revolutionary actions" that may have only further damaged Croatia's position (1972: 11), all the more so since it was his conviction that, one way or another, "Tito is politically dead" (1972: 16). The problem is, however, as Raditsa contended, that his refusal to step down or announce his successor was holding the entire country hostage (1972: 8).

We can see how Raditsa weighs in with his comments and his political acumen that was sensitive to any show of anti-democratic violence standing in for political deliberation and debate. The material offered by Raditsa's younger compeers was rife indeed. We must remember that the 1970 s were a decade of terrorism and other means of violent political strife worldwide (cf. Bilandžić 67), so that the actions undertaken by certain minority segments of the Croatian emigration fit the bill and showed certain parallels with other politically minded and active groups (both on the right and the left end of the political spectrum). ${ }^{8}$ Raditsa found himself bewildered, if not appalled, 
by the turn of events in a number of high-profile cases involving Croatian political emigrants. To name but a few in the turbulent 1970s, there was the alleged terrorist group incursion into Yugoslav territory in 1972 known as the Bugojno incident, which was swiftly foiled by the authorities with most of the infiltrators being killed and the few survivors being sentenced to death or long-term imprisonments by court marshal; the hijacking of a TWA airliner executed in the United States by an underground formation headed by Zvonko Bušić in 1976; several cases of extortion and blackmail in the Croatian emigrant communities in the United States; the threat of political assassinations and political infighting (often spurred by Yugoslav secret-service and counterintelligence activity); and two court cases involving alleged terrorist conspiracies by Australian Croats in Australia, while the list could be extended. In addition, in 1978 there was an internationally infamous case of the intended swap of three high-profile West German members of the Rote Armee Fraktion terrorist organization (who had been apprehended in $\mathrm{Za}$ greb) for eight Yugoslav dissidents residing in West Germany (among them were six Croats who were alleged members of extremist emigrant groups). This protracted case in turn triggered other violent responses by all the parties involved. ${ }^{9}$ (As an aside, this is no place to enter a more detailed analysis of intricate links that the Yugoslav regime, while pursuing the so-called politics of non-alignment and denouncing terrorism, was maintaining with different terrorist and independence groups and movements, especially from the Third World — such as the PLO but not restricted to that, as the above case with the RAF makes clear.)

factions of Croatian emigration cf. Clissold (for a general picture and despite occasional imprecision); for an insider's view, cf. Korsky.

9 The chronology of this veritable international conundrum causing serious friction between West Germany and Yugoslavia can be followed on the pages of any major publication in the diaspora at the time. Their coverage is all the more interesting because they included foreign sources and reports, notably those from West Germany. Needless to say, reports in the Yugoslav press were streamlined and censored. For a different vantage point on the crisis but confirming its cause, course, and outlines, cf. Baković. I would like to express my gratitude to Dr. Ivica Šute for his help and advice with bibliography. 
The entanglement of terrorist and freedom movements as a response to an ideologically split world called for Raditsa's ongoing comments and reflections. An interesting perspective on where the Croatian diaspora stood in that respect can be read in his 1975 essay, where he attempts a psychological portrait of the activists. He distinguishes three groups in diaspora, namely, American Croats, Croatian Americans, and lastly and most importantly for his argument, Croatian Croats, born and raised in communist Yugoslavia. While the first two groups seem to have accommodated themselves to the conditions in their host country, the last group poses an interesting problem both in ideological and political terms. According to Raditsa, this group is violently nationalistic, not refraining even from embracing Ustasha ideas, but not denouncing social communism, either, providing that it secured an independent state. In the attainment of that goal, they are hampered by neither guilt nor awe (1975: 379), while they retain the right, so the reasoning goes, to implement all and any revolutionary means-including guerilla tactics and terrorism (ibid.). Not surprisingly, for Raditsa they exhibit clear-cut totalitarian aspects, especially considering that they turn away from America in despair over its unchanging containment politics and even try to court the support of the Soviets, thus committing an unthinkable breach according to Raditsa's staunch liberal views.

In the wake of various dramatic events, Raditsa warns in his commentary in the periodical Danica, published in Chicago, of the "cancer of terrorism," while pointing out that in recent times the name "Croatian" in the States has become almost synonymous with terrorism, its holders classified alongside the supporters of the PLO, Cubans, and Puerto Ricans (Danica, 1981: 1, 9). On the other hand, as Raditsa contends, neither the Poles nor the Ukraninians resort to terrorism. This orientation, Raditsa warns further, might delegitimize the struggle for the accomplishment of a free state. Earlier, in his 1974 concluding piece to his above-mentioned memoirs Hrvats$k a 1945$, he makes the following prediction - that by the end of the century Croatia must and will be a free state, and that such a fateful decision will have to be made by the people at home, not by the diaspora (Hrvatska 1945, 366). 
It is therefore with great misgivings that he looks at the dissipation of energy and the loss of young lives and freedom on the part of the latest and exceedingly radical fighters in the ranks of the Croatian political emigration. Furthermore, he strongly resents the use of essentially non-democratic and violent forms of activism-including political assassinations - that is totally alien both to his political habitus and to American democratic principles (Hrvatski glas, 1980: 1). True to his democratic disposition, he truly believed in the inalienable right of self-determination of a people, based on President Wilson's principles, subsequently reinforced by the United Nation's charter, and eventually so flatly betrayed by both the Versailles and the Yalta agreements. In his 1975 text, he weaves these ideas into a map of a contemporary world that breaks down into "a world of freedom" and "a world of totalitarianism" (1975: 373). In March 1975, for instance, he considers decolonization as one of the major trends of the twentieth century: "the revolutionary rise of erstwhile small and obscure nations onto the stage of history" (1975: 20). This gives wings to his reiterated argument - that the principle of independence and self-determination, of universal political and moral value, therefore must also apply to Croatia, being a matter of historical necessity (1978: 3). It is the same belief, however, that inspired the anonymous author or authors of the Declaration and the Appeal to the American People, the documents meant to be distributed during the hijacking of the TWA airliner committed in 1976, as mentioned above. ${ }^{10} \mathrm{~A}$ glance at Raditsa's thoughts, however, will suggest how this act, rightly deemed terrorist, crystallized different reactions and cemented the generational division within the Croatian emigration. Even while he could see the political logic behind the action and the lifting of silence stifling Croatia in the aftermath of the Spring's demise, he nonetheless notes a change in the ranks of the latest emigrants and somewhat ruefully remarks on their aggressiveness and non-democratic methods assumed under com-

10 Maruna's report from 1995 is the most complete chronology to date of the events following the hijacking, as he uses his position as the court interpreter for the hijackers to follow the day-to-day events in the courtroom. In the final part of his study, he presents the texts of the two documents whose authorship has not been confirmed to this day. 
munism and now used even to denounce the older generation (1979: 580). It was thus the case that the newcomers' radical methods sowed seeds of discord within the diaspora and contributed to the image of the turbulent 1970s.

Unlike his younger counterparts, Raditsa sees the inevitability of the demise of communist regimes worldwide due to the unfolding principle of universal human rights, while predicting that, within the Yugoslav fold, the principle of national self-determination will take place (Nova Hrvatska, 1979: 8 ). Given his lifelong political philosophy, only a segment of which could be presented here, for Raditsa the end did not justify the means, as was the case for his political sons. The subsequent developments will prove him right.

\section{Works Cited}

Baković, Nikola. "Hapšenje pripadnika terorističke organizacije Frakcija crvene armije u Jugoslaviji 1978. godine." Godišnjak za društvenu istoriju 1 (2011): 31-48.

Banac, Ivo. “Tito: Dok imam vojsku ne bojim se nikoga. Ne bih je volio upotrijebiti."

Večernji list. 3. 12. 2011. Sept. 24, 2014. <www.vecernji.hr>.

Batović, Ante. "Od ekonomske reforme do Brijunskog plenuma-Američki i britanski izvještaji o Hrvatskoj (1964.-1966.)." Historijski zbornik 63.2 (2010): 539-58.

Bilandžić, Mirko. Sjeme zla. Elementi sociologije terorizma. Zagreb: Plejada, Synopsis, 2010.

Brešić, Vinko. “Nacionalni kontekst emigrantske Hrvatske revije." Hrvatska revija XIII/ 4 (2014): 62-64.

Clissold, Stephen. “Croat Separatism: Nationalism, Dissidence and Terrorism." Conflict Studies 103 (January 1979): 1-21.

Domankušić, Stjepan i Milivoje Levkov. Politička emigracija. Aktivnosti političke emigracije protiv samoupravne socijalističke Jugoslavije i njenih oružanih snaga. Beograd:

Vojnoizdavački zavod, 1974.

Đurašković, Stevo. "Zaboravljeni hrvatski kozmopolit Bogdan Radica." Dijalog povijesničara/ istoričara 10. Sv. 1. Ur. Igor Graovac. Zagreb: Friedrich Naumann Stiftung, 2008. 307-25.

Fluck, Winfried, Donald Pease and John Carlos Rowe, eds. Re-Framing the Transnational

Turn in American Studies. Dartmouth: Dartmouth College P, 2011.

Jakovina, Tvrtko. “Idealističkoj, hrabroj i (ludoj) mladosti.” Ponoš 5-12. 
Jakovina, Tvrtko, ur. Hrvatsko proljeće 40 godina poslije. Zagreb: Centar za demokraciju Miko Tripalo; Filozofski fakultet; Fakultet političkih znanosti; Pravni fakultet, 2012.

Korsky, Ivo. “Da li postoji hvatski terorizam?” Hrvatski tjednik V/ 207. 20. 10. 1981, 15.

Kullaa, Rinna. "US Intelligence Estimates of 'The Crisis in Croatia' and Its Relationship to Détente in East-West Relations Across Europe 1971-1972.” Jakovina 93-109.

Listeš, Srećko. Hrvatska revija (1951.-1990.) i hrvatska emigrantska književnost. Doktorska disertacija Sveučilišta u Zadru, Zadar, 2011.

Maruna, Boris. Otmičari ispunjena sna. Zagreb: Mozaik knjiga, 1995.

Ponoš, Tihomir. Na rubu revolucije: studenti '71. Zagreb: Profil, 2007.

Radica, Bogdan. Hrvatska 1945. 1974. Zagreb: Grafički zavod Hrvatske, 1992.

--- . Bogdan Radica: Hrvatska država do kraja ovog stoljeća.” Nova Hrvatska, 16. rujna 1979, 8.

--- . “Hrvatska 1970.” Hrvatska revija XX/4 (80) (Prosinac 1970): 513-33.

--- . "Hrvatska nakon Karađorđeva. Prah i pepeo pobjede i poraza." Hrvatska revija XXIII/1 (89) (Ožujak 1973): 3-18.

--- . Hrvatska u očekivanju novog stoljeća." Hrvatska revija XIX/4 (116) (Prosinac 1979): 571-83.

--- . "Hrvatska u sadašnjoj krizi Euro-Amerike." Hrvatska revija XXIV/1 (93) (Ožujak 1974): 3-15.

--- . "Hrvatska tragedija u Americi." Hrvatski glas. January 22, 1980, 1.

--- . "Izbjegla Hrvatska na prekretnici svijeta." Hrvatska revija XXV/3 (99) (Rujan 1975): 373-84.

--- . 'Malenkov's 'Liberal' Concessions Put the Heat on Dictator Tito." Editorial. Saturday Evening Post. June 13, 1953, 12.

--- . "Pogled na nas." Hrvatska revija XXVIII/3 (111) (Rujan 1978): 357-76.

--- . "Rak terorizma." Danica Vol. 51, No. 22. May 29, 1981, 1, 9.

--- . “Some Displaced Intellectuals Mistake U.S. for 'Lubberland.” Editorial. Saturday Evening Post. October 7, 1950, 12.

--- . Svijet i Hrvatska u očekivanju novog stoljeća." Hrvatska revija XXV/1 (99) (Ožujak 1975): 19-30.

--- . Vječni Split. Izabrala i priredila Jelena Hekman. Split-Zagreb: Ex Libris, 2002.

--- . "Vjera u pobjedu nezavisnosti-vjera u budućnost Hrvatske." Hrvatska revija 
XXVIII/1 (109) (Ožujak 1978): 3-15.

--- . “Yugoslavia Will Be a New Headache If We Don’t Play Our Cards Right." Editorial. Saturday Evening Post. Jan. 27, 1951, 12.

--- . "Zlokobni prosinac 1971." Hrvatska revija XXII/ 1 (85) (Ožujak 1972): 3-16.

Rullmann, Hans. “Bruno Bušić.” Hrvatski glas. 10. studenoga 1983, 16. 